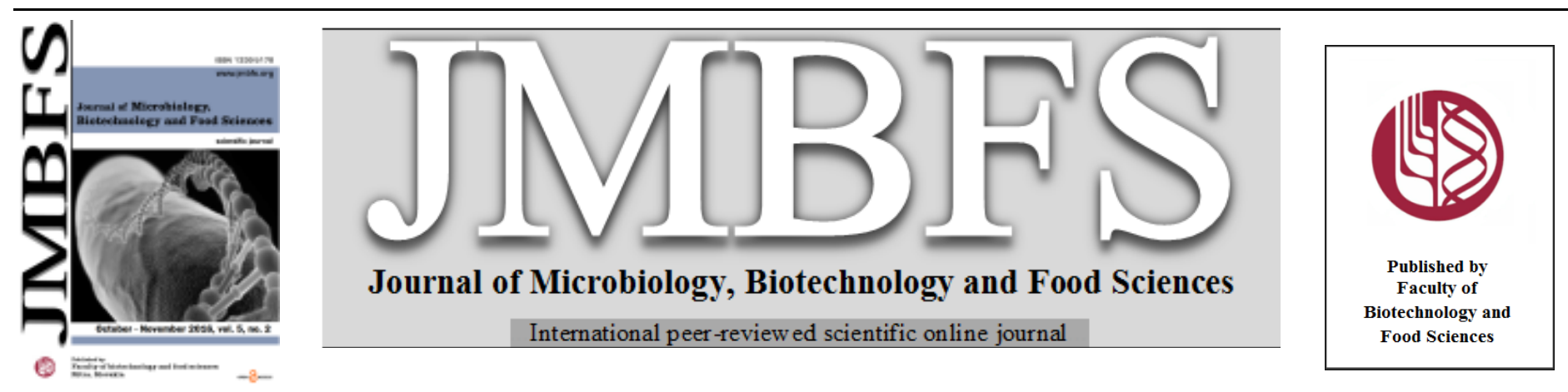

\title{
OPTIMIZATION, PRODUCTION, PARTIAL PURIFICATION AND CHARACTERIZATION OF NEUTRAL AND ALKALINE PROTEASES PRODUCED BY BACILLUS SUBTILIS
}

\author{
Mark Kevin P. Devanadera ${ }^{* 1,2}$, Stephanie Vannie O. Haw ${ }^{1}$, Merry Joy J. Arzaga ${ }^{1}$, Lovely Jenny Buenaflor ${ }^{1}$, Twinkle Joy E. Gagarin ${ }^{l}$, \\ Andrea G. Vargas ${ }^{1,3}$, Susana M. Mercado ${ }^{4,5,6}$, Librado A. Santiago ${ }^{1,2,3}$
}

\begin{abstract}
Address(es): Mark Kevin P. Devanadera
${ }^{1}$ Department of Biochemistry, Faculty of Pharmacy, University of Santo Tomas, Manila, Philippines $1015,{ }^{2}$ Graduate School, University of Santo Tomas, Manila, Philippines 1015, ${ }^{3}$ Research Center for Natural and Applied Sciences, University of Santo Tomas, Manila, Philippines $1015,{ }^{4}$ National Institute of Molecular Biology and Biotechnology(BIOTECH), College, Los Baños, Laguna, Philippines 4031, Institute of Chemical Engineering, University of the Philippines Los Baños, Laguna, Philippines 4031, ${ }^{6}$ Institute of Food Science, University of the Philippines Los Baños, Laguna, Philippines 4031
\end{abstract}

*Corresponding author: markkevindevanadera@yahoo.com

doi: 10.15414/jmbfs.2016.6.2.832-838

ARTICLE INFO

Received 7. 10. 2014

Revised 27. 6. 2016

Accepted 12. 7. 2016

Published 3. 10. 2016

Regular article

open OACCESS $_{\text {act }}$

\begin{abstract}
Different strains of Bacillus subtilis (Ehrenberg) Cohn, BIOTECH 1056, 1333, 1573 and 1679, UPCC 1295 and USTCMS 1011 from various culture collections in the country were characterized morphologically, biochemically, and assayed for proteolytic activity. Fermentation parameters like $\mathrm{pH}$, temperature, and incubation time were optimized for the production of proteases that were used as gauges to select the best bacterial isolates for possible commercial application. Among the six isolates studied, USTCMS 1011 gave the highest neutral protease activity of $0.647 \mathrm{U} / \mathrm{mg}$ protein at $\mathrm{pH} 7$ and at $37^{\circ} \mathrm{C}$ for 72 hours. The same strain yielded the highest alkaline protease activity of $0.495 \mathrm{U} / \mathrm{mg}$ protein at $\mathrm{pH} 9$ and at $30^{\circ} \mathrm{C}$ for 72 hours. Various beans and fruit extracts or honey were tested as possible protein or carbohydrate sources in the medium. Dextrin produced the highest protease activity with $0.647 \mathrm{U} / \mathrm{mg}$ protein for neutral protease and $0.495 \mathrm{U} / \mathrm{mg}$ protein for alkaline protease as carbohydrate source. Garbanzos (chickpea) as protein source, supplemented with yeast extract, gave the highest protease activity at $0.548 \mathrm{U} / \mathrm{mg}$ protein for neutral protease and $0.475 \mathrm{U} / \mathrm{mg}$ protein for alkaline protease. Both crude proteases were purified by ammonium sulfate precipitation followed by desalting and gel filtration chromatography. Optimal activity of the neutral protease was found at $\mathrm{pH} 8$ and $30^{\circ} \mathrm{C}$ with an incubation time of $90 \mathrm{~min}$ while optimal activity of the alkaline protease was at $\mathrm{pH} 11$ and $40^{\circ} \mathrm{C}$ with only $30 \mathrm{~min}$ incubation period. Neutral protease showed a single band with molecular weight of $65.4 \mathrm{kDa}$ in SDS-PAGE while alkaline protease showed single band with molecular weight of $8 \mathrm{kDa}$.
\end{abstract}

Keywords: USTCMS 1011, Gel Filtration Chromatography, Bacillus subtilis, Neutral Protease, Alkaline Protease

\section{INTRODUCTION}

Proteases are essential constituent of all forms of life on earth that function to hydrolyze proteins into smaller fragments. It has been widely used as an important industrial enzyme, occupying nearly $60 \%$ of the enzyme sales that are obtained from microorganisms, plants and animals. Proteases have been commercially used for the production of household laundry detergents (Kumar et al, 2002), medicine and poultry feeds (Beijing Shifa Technology and Trade Co., Ltd.). Proteases can be isolated from different biological sources. One of the most utilized sources of proteases are the extracellular proteins secreted from the membrane of microorganisms such as $B$. subtilis. These bacterial species are obligate aerobes, mesophiles and spore-forming that are commonly found in the soil. They are stable at $\mathrm{pH}$ ranging from 5-11. These bacteria are noted for its ability to degrade plant polysaccharides and pectin. The production of microbialderived proteases is most advantageous and economically competitive since they are easy to produce commercially at a fast rate and requires less space. Bulk enzymes are preferred over "fine" enzymes, because they are less expensive and can be produced in higher quantity, though it has an inherently lower unit value (Kumar et al, 2002). But in terms of relationship between scale values and market volume requirement, proteases command higher enzyme preparation value over pectinase, glucoamylase and amylase. However, environmental and cultural conditions for fermentation are ought to be optimized to obtain higher yield of proteases. Prior to this work, individual independent studies have been carried out on the various strains of $B$. subtilis though no single study has ever been conducted using the four strains of B.subtilis namely BIOTECH 1056, BIOTECH 1573, UPCC 1295 and USTCMS 1011 by comparing their activities to that of the previously studied strains, BIOTECH 1333 and BIOTECH 1679 (Espino et al., 1996). Two of the bacterial isolates, BIOTECH 1573 and USTCMS 1011, were both soil isolates from the Philippines. In general, crude proteases can be produced at a less expensive cost and in higher quantity by using cheap sources of proteins and carbohydrates.

\section{MATERIALS AND METHODS}

\section{Chemicals and Reagents}

Analytical grade reagents were used in all the experiments. The agars and broths used in the study were purchased from HiMedia Laboratories Pvt. Ltd., India. Other chemicals used for the purification method were obtained from SigmaAldrich Co., St. Louis, MO, USA and Scharlau Chem-Supply, Gillman, South Australia.

\section{Microorganisms}

Different $B$. subtilis isolates namely, B. subtilis MNH (BIOTECH 1056), B. subtilis (Ehrenberg) Cohn (BIOTECH 1333), B. subtilis BIOTECH 1573 (Philippine soil isolate), and B. subtilis NRRL B-3749 (BIOTECH 1679) were obtained from the Philippine National Collection of Microorganisms (PNCM) at the National Institute of Molecular Biology and Biotechnology (BIOTECH), University of the Philippines Los Baños, Laguna, Philippines while B. subtilis FIRDI 10447 (UPCC 1295) was obtained from the UP Culture Collection, Natural Science Research Institute, University of the Philippines Diliman, Quezon City, Philippines. The B. subtilis USTCMS 1011(Philippine soil isolate) was acquired from the UST Collection of Microbial Strains, Research Center for the Natural and Applied Sciences of the University of Santo Tomas, España, Manila, Philippines. 


\section{Microorganism's culture condition and inoculum preparation}

Inoculum preparation was done according to the culture conditions and method of El-Safey and Abdul-Raouf (2003). The pure culture of B. subtilis was maintained in nutrient agar. A 24-hr bacterial culture was maintained in nutrient agar medium at $4^{\circ} \mathrm{C}$ and subculture was done by streak plate method. Initially, the growth of the bacterial culture and the production of proteases were observed in skimmed milk agar. For every experiment, a 24-hr subculture of microorganism grown in a sterile nutrient agar at $37^{\circ} \mathrm{C}$ was used. The strain was preserved by inoculating a loopful of the strain into a nutrient broth medium with $70 \%$ glycerol and stored at $-20^{\circ} \mathrm{C}$.

\section{Morphological Characterization of $B$. subtilis}

Each of the six strains of $B$. subtilis was subjected to morphologica characterization such as Gram staining, spore staining and capsule staining methods. The slides were viewed at High Power and Oil Immersion Objectives and documented.

\section{Biochemical Characterization of $B$. subtilis}

Each strain of $B$. subtilis was cultured in different media such as Mac Conkey Agar, Mannitol Salt Agar, Triple Sugar Iron Agar, Simmon Citrate Agar, and Litmus Milk Agar to test for any biochemical reactions. Furthermore, the bacterial strains were also screened for catalase activity.

\section{Media for Proteases Production and Submerged Fermentation}

Fermentation was performed with some modifications (Das and Prasad, 2010) The fermentation medium used for protease production consists of the following in $1 \mathrm{~L}$ of solution: $60 \mathrm{~mL}$ soybean pressed cake extract (SPC extract), $13 \mathrm{~g}$ $\mathrm{KH}_{2} \mathrm{PO}_{4}, 0.3 \mathrm{~g} \mathrm{MgSO}_{4} \bullet 7 \mathrm{H}_{2} \mathrm{O}, \mathrm{FeSO}_{4} \bullet 7 \mathrm{H}_{2} \mathrm{O}, 8 \mathrm{~g}$ dextrin, $0.5 \mathrm{~g} \mathrm{KCl}, 0.2 \mathrm{~g} \mathrm{CaCl}_{2}$, $2.0 \mathrm{~g}$ yeast extract.

\section{Optimization of Protease Production}

\section{A. Effect of pH on Protease Production}

The $100 \mathrm{~mL}$ media for protease production were prepared in various $\mathrm{pH}(4.0,7.0$ 9.0 and 10.0) and were inoculated with one loopful of $B$. subtilis and incubated at $37^{\circ} \mathrm{C}$ using a shaker incubator in $100 \mathrm{rpm}$ for $72 \mathrm{hrs}$. The protease produced was then measured using casein assay and protein assay (Das and Prasad, 2010).

\section{B. Effect of Incubation Temperature on Protease Production}

The media for protease production were incubated at different temperatures $(30$, $35,37,39,40^{\circ} \mathrm{C}$ ) at $\mathrm{pH} 6$ and were inoculated with one loopful of B. subtilis and incubated for $72 \mathrm{hrs}$. The protease produced was measured using casein assay and protein assay (Das and Prasad, 2010).

\section{Effect of Incubation Time on Protease Production}

The effect of incubation time was determined by incubating one loopful of bacterial isolates in the medium for protease production at different incubation time $(24,48,144,168 \mathrm{hrs})$ at optimum $\mathrm{pH}$ and temperature. The protease produced was measured using casein assay and protein assay (El-Safey and Abdul-Raouf, 2004).

\section{Effect of Modifying Carbohydrate and Protein}

\section{Media Composition on Protease Production}

This was determined by fermenting a loopful of $B$. subtilis in modified media composition. Soybean pressed cake extract and dextrin were incorporated to the medium as standard nitrogen and carbon sources, respectively. Other sources such as garbanzos (chickpea) extract, black bean extract, and mung bean extract were used as new possible nitrogen sources, at $0.6 \%$ concentration and were incorporated in the media for protease production (nutrient medium stated above) aside from soy bean pressed cake extract. Whereas, mango extract, banana extract and honey, tested as alternative carbon sources, at $0.8 \%$ concentration were incorporated in the media as new carbon sources for protease production other than dextrin.

\section{Enzyme Production}

Different strains of $B$. subtilis were fermented using the optimized fermentation parameters and media composition for protease production. Optimum $\mathrm{pH}$ was used by adjusting the initial $\mathrm{pH}$ of the media using $\mathrm{Na}_{2} \mathrm{CO}_{3}$. The propagation medium was sterilized at $121^{\circ} \mathrm{C}$ for $15 \mathrm{~min}$. The medium $(10 \mathrm{ml}$ in $250 \mathrm{~mL}$ Erlenmeyer flask) was inoculated with a loopful of $B$. subtilis and incubated at optimized temperature and incubation time in a rotary shaker (Thermoshaker Max Q4000, Thermo Scientific, USA) operated at $200 \mathrm{rpm}$ for $72 \mathrm{hrs}$.

\section{Product recovery}

After incubation, the medium was centrifuged at 3,000 to 13,000 rpm (KUBOTA KS-5000P, Kubota, Japan) at $4^{\circ} \mathrm{C}$ for $15 \mathrm{~min}$ to separate the microbial cells. The supernatant was collected because it contains the extracellular enzyme that was secreted by the bacteria. The collected solution was stored at $4^{\circ} \mathrm{C}$ until further use.

\section{Purification of Proteases}

\section{A. Ammonium Sulfate Precipitation}

The bacterial supernatant was fractionated by using ammonium sulfate with $80 \%$ of saturation and was salted out using the desired buffer for the enzyme. All steps were carried out at $4 \mathrm{oC}$. The proteins were re-suspended at $0.1 \mathrm{M}$ Tris- $\mathrm{HCl}$ buffer at $\mathrm{pH} 7.8$ for neutral proteases and $0.1 \mathrm{M}$ glycine- $\mathrm{NaOH}$ at $\mathrm{pH} 10-11$ for alkaline proteases (Adinarayana et al, 2003).

\section{B. Dialysis}

Dry membranes (Sigma D9652-100FT Dialysis tubing cellulose membrane, Sigma-Aldrich) were used for the dialysis of the collected protease, the dialyzing bag was boiled using distilled water with EDTA. The dialyzing buffer used was the same as the buffer used in desalting the enzymes. Both types of enzymes were purified using this technique. The enzyme was recovered from the membrane and stored at $4^{\circ} \mathrm{C}$ until further use.

\section{Gel-filtration Chromatography}

The protein obtained after precipitation with $80 \%$ ammonium sulfate was dissolved in the desired buffer, dialyzed and loaded into a column of Sephadex G-75 (Sigma-Aldrich) equilibrated with 0.1 M Tris-HCl buffer at $\mathrm{pH}$ 7.0-8.0 for neutral protease and $0.1 \mathrm{M}$ glycine- $\mathrm{NaOH}$ buffer at $\mathrm{pH} 10.0-11.0$ for alkaline protease. The chromatography was performed at a flow rate of $60 \mathrm{~mL} /$ hour using the same buffer. Five milliliters of eluate were collected per fractions. Collected proteases have high caseinase activity and demonstrated high peaks at $280 \mathrm{~nm}$.

\section{Characterization of Purified Enzymes}

\section{A. Effect of pH on enzyme activity and stability}

The activity of purified enzyme was measured at different $\mathrm{pH}$ values $(2.0-11.0)$ The $\mathrm{pH}$ was adjusted using phosphate-citrate buffer $(\mathrm{pH}$ 2.0-7.0), Tris- $\mathrm{HCl}$ buffer (pH 8.0), and glycine- $\mathrm{NaOH}$ buffer ( $\mathrm{pH}$ 9.0-11.0). The mixture was incubated at $40^{\circ} \mathrm{C}$ for $30 \mathrm{~min}$ and the activity of the enzyme was measured. The stability of the enzyme was determined using different buffers $(\mathrm{pH} 2.0-11.0)$ and was incubated for $48 \mathrm{hrs}$. The activity of the enzyme at each exposure in different $\mathrm{pH}$ and time were measured using casein assay and protein assay.

\section{B. Effect of temperature on enzyme activity and stability}

The activity and stability of the purified enzyme were both determined by incubating the mixture at different temperatures $\left(20,30,40,50\right.$ and $\left.60^{\circ} \mathrm{C}\right)$ for 30 min and 1 hour, respectively. The activity of the enzyme at the different temperatures and their stability were measured using casein assay and protein assay (Adinarayana et al, 2003) (Das and Prasad, 2010).

\section{Effect of Incubation Period}

The purified protease was incubated at $40^{\circ} \mathrm{C}$ at their respective $\mathrm{pH}$ and incubated for of $30,60,90,120,150$ and $180 \mathrm{~min}$. The enzyme activity was determined using casein assay and protein assay.

\section{Homogeneity determination using SDS-PAGE}

Fractions with high activity in casein assay from gel chromatography were run in SDS-PAGE. Two (2) microliter of sample were mixed with $2.5 \mu \mathrm{L}$ Bolt ${ }^{\circ}$ LDS Sample Buffer (4x) (Novex, USA), $1 \mu \mathrm{L}$ Bolt ${ }^{\circledR}$ Reducing Agent (10x) for reduced samples and none for non-reduced samples and brought the final volume to $10 \mu \mathrm{L}$ using ultra-pure water. The samples were incubated for 10 minutes at $70^{\circ} \mathrm{C}$. Ten microliter of samples and standard were loaded in a pre-cast gel (Bolt $₫$ Mini Gels, Novex, USA). The pre-cast gel was placed in Bolt $₫$ ) Mini Gel Tank (Novex, USA) and added with $400 \mathrm{~mL}$ of $1 \mathrm{X}$ MES Running buffer (Novex, USA). The running condition set for the gel was $80 \mathrm{~V}$ and run for 60 minutes. After running, the gels were stained with Coomassie Blue R-25 (Sigma-Aldrich, USA) and destained using methanol and acetic acid. Protein standard used was SeeBlue ${ }^{\circledR}$ Plus2 Prestained Standard (Novex, USA). 


\section{Tyrosine Standard Curve}

Stock solution of tyrosine was prepared at $100 \mu \mathrm{g} / \mathrm{ml}$ and aliquots of which were prepared $(10-100 \mu \mathrm{g})$ then was read at $280 \mathrm{~nm}$. The standard curve was composed of tyrosine concentrations versus the absorbance at $280 \mathrm{~nm}$ (Kumar $\boldsymbol{e t}$ al, 2002).

\section{Casein Assay}

A $2.5 \mathrm{~mL}$ casein solution of $0.6 \%$ casein in $0.01 \mathrm{M}$ Tris- $\mathrm{HCl}(\mathrm{pH} 7.2)$ or $0.01 \mathrm{M}$ glycine- $\mathrm{NaOH}(\mathrm{pH} 10)$ was incubated with $0.5 \mathrm{~mL}$ of diluted enzyme solution for $30 \mathrm{~min}$ at $40^{\circ} \mathrm{C}$. The reaction was stopped by adding $10 \%$ trichloroacetic acid (TCA) solution. After $30 \mathrm{~min}$, the mixture was centrifuged at $10,000 \mathrm{rpm}$ for 5 min. The enzyme activity was then calculated from the standard curve of L tyrosine. in the Absorbance of each concentration of tyrosine $(10-100 \mu \mathrm{g} / \mathrm{mL})$ read at 275 or $280 \mathrm{~nm}$ for the preparation of the standard graph. Enzymatic activity which was measured as one unit, means that one amount of enzymatic activity reacts with one micromole of substrate per minute of reaction. Enzyme activity was dependent on the temperature, particular $\mathrm{pH}$, substrate concentration and the active site of enzyme (Espino et al, 1996; Kumar et al, 2002).

\section{Protein Assay}

The protein concentration was measured using Lowry method using bovine serum albumin (BSA) as the standard. The concentration of protein during purification studies was measured at $280 \mathrm{~nm}$.

\section{Statistical Analysis}

The incubation parameters and other conditions were statistically analyzed by one-way analysis of variance (ANOVA) using MS Excel determine the effects of different variables. The $p<0.05$ value was considered to be significant.

\section{RESULTS}

Six strains of $B$. subtilis were collected from different culture collections in the Philippines and screened for proteolytic activity. The different strains of bacteria were partially identified to confirm the identity of the bacteria from the culture collections and then preceded to identification of best strain that produced proteases through optimization of fermentation parameters like temperature and $\mathrm{pH}$ independently. Some of the strains are known to produce proteases and some of the strains acquired from different culture collections are studied to produce proteases (BIOTECH 1573 and BIOTECH 1679) while some (USTCMS 1011, UPCC 1295, BIOTECH 1056, BIOTECH 133) are not yet screened and studied to produced proteases.

\section{Partial Identification of Six Strains of B.subtilis}

The results of morphological and biochemical characterization confirmed the identity of the B. subtilis strains that were used in the study. The results showed that they were all gram positive, spore forming and encapsulated bacteria that were lactose and glucose fermentor and can produce catalase. The six strains of B. subtilis showed a negative result in Mannitol Salt Agar (MSA) since the agar is specific for Staphylococcus aureus, negative in Simmon Citrate Agar (SCA) and MacConkey Agar (MCA) since both media are selective for Escherichia coli.

\section{Fermentation Parameters}

Tyrosine standard curve was used to determine the proteolytic activity of the enzyme based on its reactivity towards the substrate and was used to determine enzyme activity in each fractions of purification. The protein concentration was determined based on the absorbance acquired and was used to compute the specific activity of the enzyme. (The linear equation obtained from the standard curve was $y=0.002 x+0.0197$ with a linearity $\left(R^{2}\right)$ value of 0.9929 . The equation was significant on the whole research since it was used to determine the enzymatic activity throughout production, purification, and optimization.

The $\mathrm{pH}$ of the media and the incubation temperature were optimized for the production of neutral and alkaline proteases with highest activity. The six different strains of $B$. subtilis were incubated at different temperatures and different $\mathrm{pH}$ of the media. Results are shown in Figure 1 and 2.

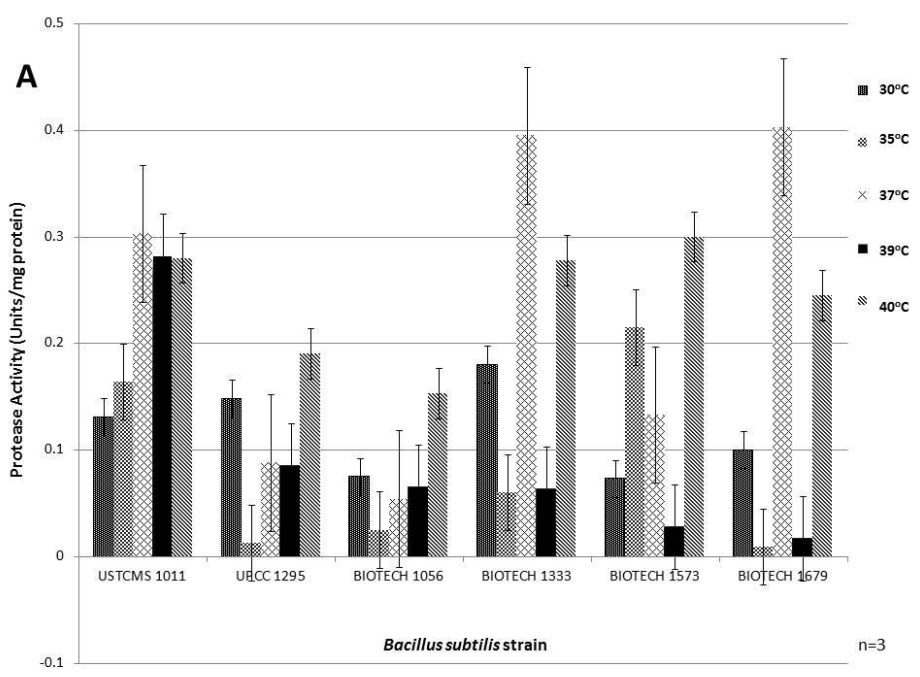

Figure 1A Neutral protease activities (U/mg protein) of six strains of Bacillus subtilis at different incubation temperature using media for protease production according to Das and Prasad, 2010 and Espino et al, 1992 at pH 6.

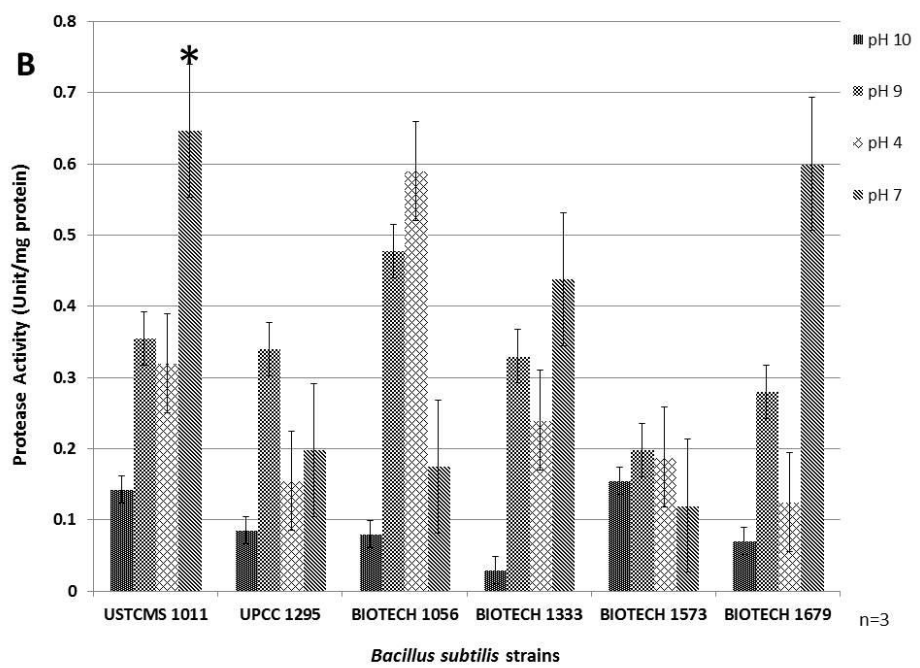

Figure 1B Neutral protease activities (U/mg protein) of six strains of Bacillus subtilis at different $\mathrm{pH}$ medium using media for protease production according to Das and Prasad, 2010 and Espino et al, 1992 at $37^{\circ} \mathrm{C}$.

Evaluating the two graphs (Fig. 1A and 1B), it showed that the strain USTCMS 1011 produced the highest neutral protease activity $(0.6466 \pm 0.05 \mathrm{U} / \mathrm{mg})$ based on the fermentation parameters at $\mathrm{pH} 7.0$. and at $37^{\circ} \mathrm{C}$ and thus was used in the protease production experiment.

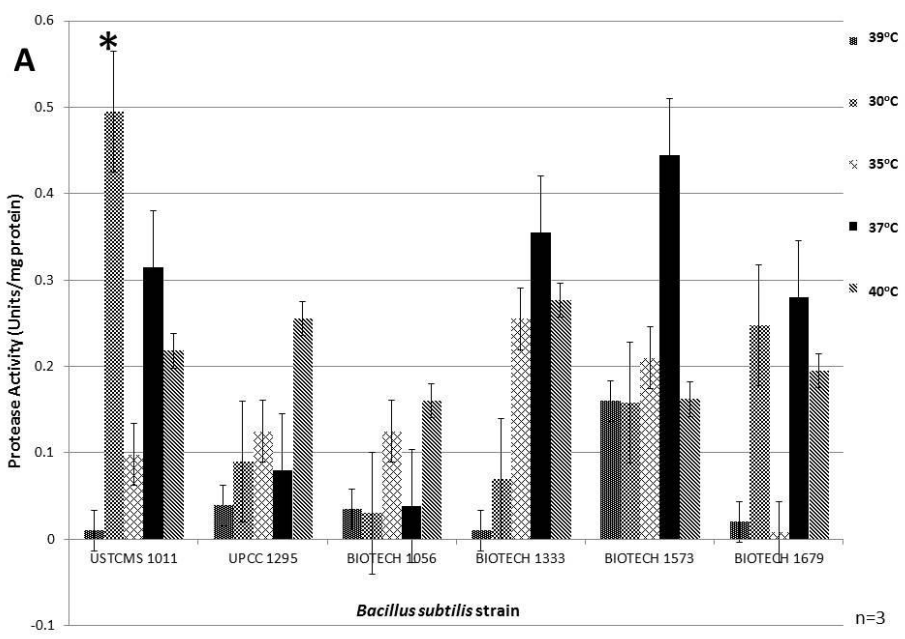

Figure 2A Alkaline Protease activities (U/mg protein) of six strains of Bacillus subtilis at different incubation temperature using media for protease production according to Das and Prasad, 2010 and Espino et al, 1992 at pH 9. 


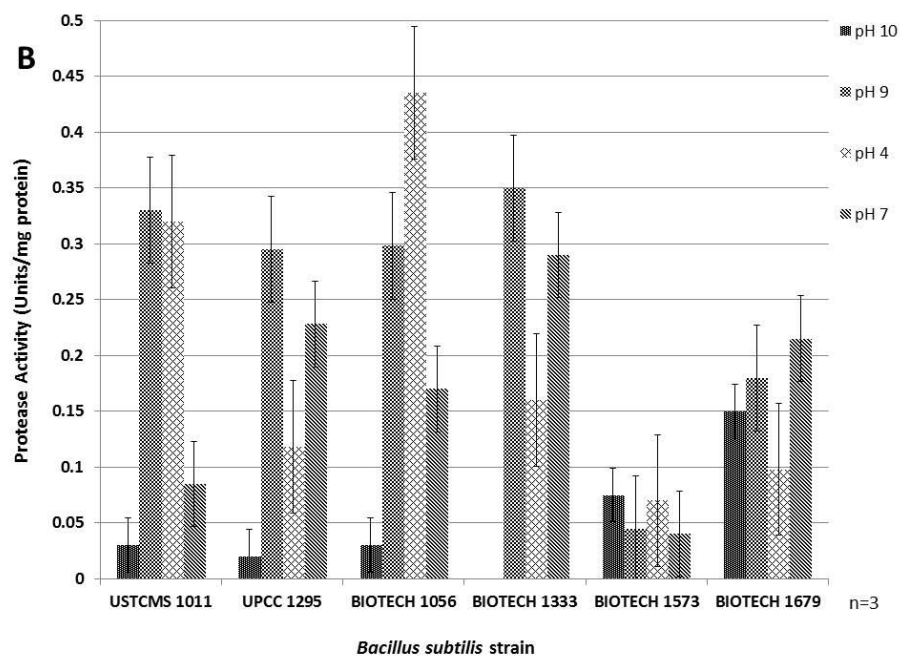

Figure 2B Alkaline Protease activities (U/mg protein) of swix strains of Bacillus subtilis at different $\mathrm{pH}$ medium using media for protease production according to Das and Prasad, 2010 and Espino et al, 1992 at $32^{\circ} \mathrm{C}$
Figure 2 illustrates the alkaline protease activity at different $\mathrm{pH}$ of media and different incubation temperature. USTCMS 1011 had the highest alkaline protease activity based on the two graphs that yielded $0.4954 \pm 0.032 \mathrm{U} / \mathrm{mg}$. Since USTCMS 1011 gave a significantly highest alkaline protease activity $(\mathrm{p}<0.05)$, it was used for the production of the alkaline protease at $\mathrm{pH} 9$ and at $30^{\circ} \mathrm{C}$.

\section{Media Composition}

Additional fermentation parameters were optimized in this study such as the media compositions wherein different protein and carbohydrate sources were used. The protein and carbohydrate sources that gave the highest proteolytic activity was used for the production of laboratory scale enzymes. The concentration of the protein and carbohydrate sources used was $0.6 \%(\mathrm{w} / \mathrm{v})$ and $0.8 \%(w / v)$, respectively. Results are shown in Figure 3.

Black beans, garbanzos and mung beans,incubated with or without yeast, were used as protein sources.Statistical analysis showed significant differences among different protein sources. Optimum proteolytic activity was found when garbanzos with yeast was used, where highest protein activity for both alkaline and neutral protease at $0.4754 \pm 0.028 \mathrm{U} / \mathrm{mg}$ protein and $0.5476 \pm 0.041 \mathrm{U} / \mathrm{mg}$, respectively were recorded. Results are shown in Fig. 3A

Incubation time of $24,48,72,144$, and 168 hours were used in the experiment (data not shown). At 72 hours, both the neutral and alkaline proteases significantly yielded the highest proteolytic activity $(\mathrm{p}<0.05)$. Neutral protease gave $0.6466 \pm 0.05 \mathrm{U} / \mathrm{mg}$ protein and alkaline protease gave $0.4955 \pm 0.032 \mathrm{U} / \mathrm{mg}$ protein. Results are shown in Fig. 3C.
A

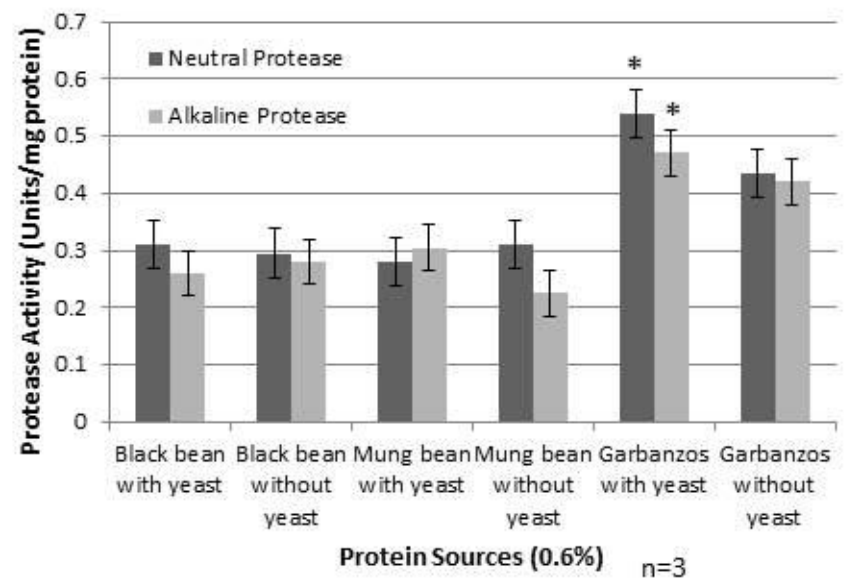

B

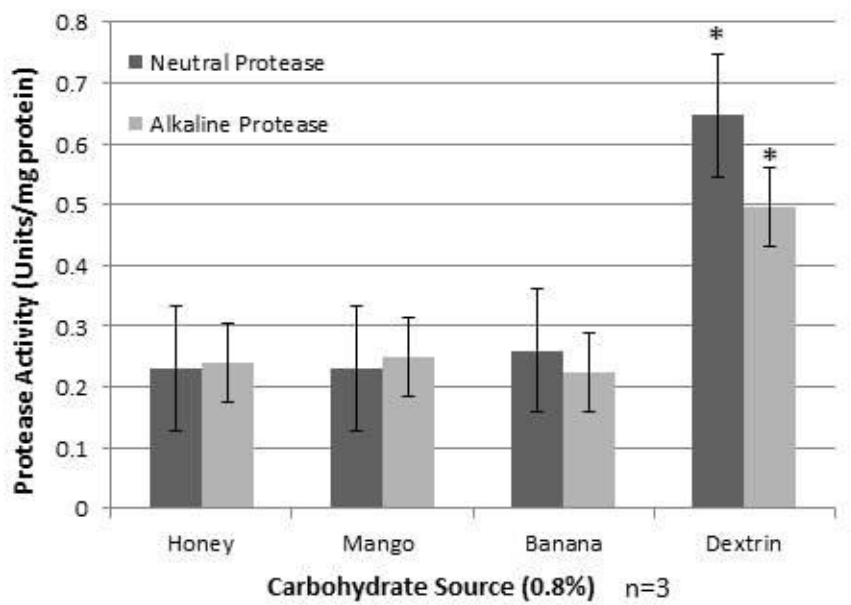

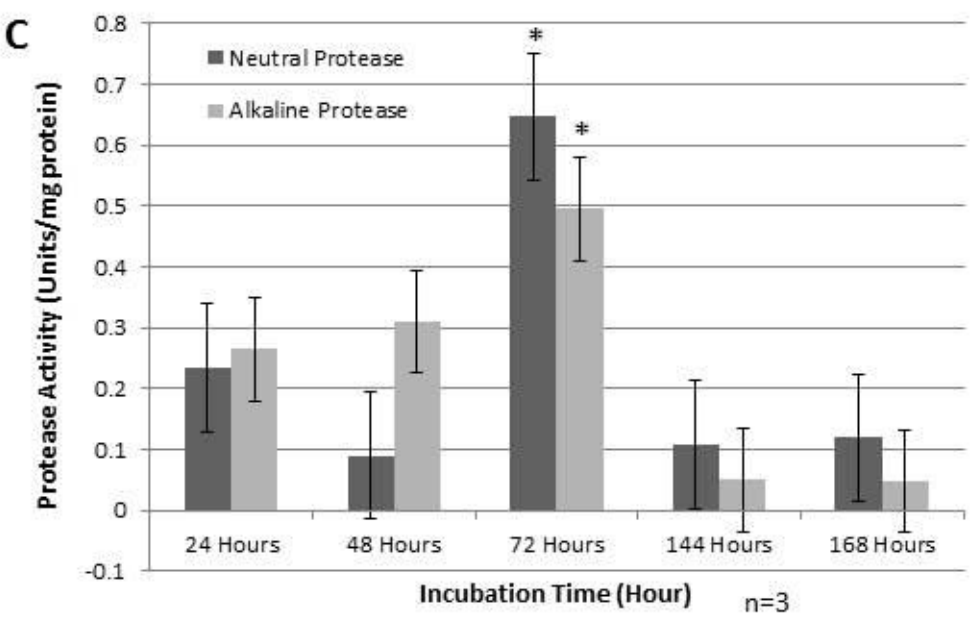

Figure 3 (A) Neutral and Alkaline protease activity (U/mg protein) of B. subtilis USTCMS 1011 at different protein sources with a concentration of $0.6 \%$ incorporated in the media for protease production according to Das and Prasad, 2010 and Espino et al, 1992 at $\mathrm{pH} 7,37^{\circ} \mathrm{C}$ and $\mathrm{pH} 9,30^{\circ} \mathrm{C}$ respectively. (B) Neutral and Alkaline protease activity (U/mg protein) of USTCMS 1011 at different carbohydrate sources with a concentration of $0.8 \%$ incorporated in the media for protease production according to Das and Prasad, 2010 and Espino et al, 1992 at $\mathrm{pH} 7,37^{\circ} \mathrm{C}$ and $\mathrm{pH} 9,30^{\circ} \mathrm{C}$ respectively. (C) Effect of different incubation time (hours) on USTCMS 1011 production of neutral and alkaline protease using the media for protease production according to Das and Prasad, 2010 and Espino et al, 1992 at $\mathrm{pH} 7,37^{\circ} \mathrm{C}$ and $\mathrm{pH} 9,30^{\circ} \mathrm{C}$ respectively.

\section{Purification by Gel Filtration}

Neutral and alkaline proteases were produced from B. subtilis USTCMS1011 by using the optimized fermentation parameters and media composition. The protease was partially purified by salting-in in a solution of ammonium sulfate
(\% w/v) and desalting the enzyme by dialysis. The dialyzed product was subjected to gel filtration for further purification. The absorbance of each fraction that were collected were read at $280 \mathrm{~nm}$ to detect the presence of proteins. High peak at $280 \mathrm{~nm}$ indicated the presence of the enzyme on the different fractions. The fractions were also assayed using casein assay to constantly 
monitor the presence and the activity of the enzyme in each fractions. Results are shown in Figure 4.

The test for protease acivity of neutral protease was done at $280 \mathrm{~nm}$. This test was used to confirm the presence of neutral protease on the different fractions (shown in Fig. 4A). The highest protease activity at 18.411 units $/ \mathrm{mL}$ in the reaction mixture was observed in fraction 5. The fraction with the highest proteolytic activity was collected and used for optimization of partially purified enzyme.Similarly, the test for alkaline protease activity was done at $280 \mathrm{~nm}$. This test was used to confirm the presence of alkaline protease on the different fractions (shown in Fig. 4B). The highest protease activity at 11.064 units $/ \mathrm{mL}$ was observed in fraction 5. Figure 4B also showed the high peak and high protease activity in fractions 5 and 6 . The presented data was in enzyme activity (units $/ \mathrm{mL}$ ) since protease activity was being determined on the gel purification and not the specific activity (units/mg protein) of the enzyme in relation to its substrate.
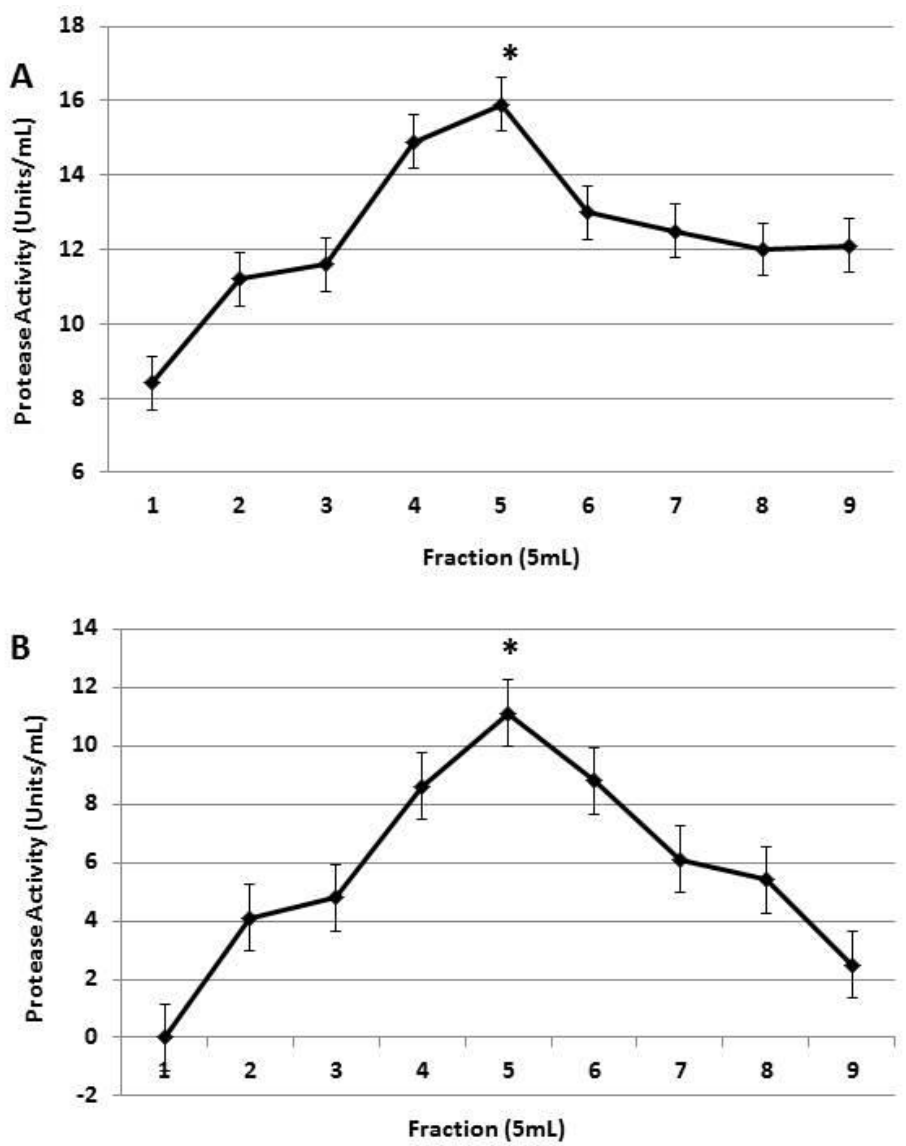

Figure 4 (A) Total neutral protease activity $(\mathrm{U} / \mathrm{mL})$ after gel filtration chromatography of $5 \mathrm{~mL}$ per fraction. (B) Total alkaline protease activity $(\mathrm{U} / \mathrm{mL})$ after gerl filtration chromatography of $5 \mathrm{~mL}$ per fraction.

\section{Purification of Crude Enzyme}

The total activity and total protein were determined using casein assay and protein assay (Lowry method). After the determinations, the total protein, specific activity, percentage yield, and the purification fold of the enzyme were calculated. Results are shown in Table 1 and 2.

The purification folds for gel-filtration chromatography were 31.719 and 1.330 for neutral and alkaline proteases respectively.

The trend on the total protein, total activity, specific activity, percentage yield, and purification fold based on the different purification steps. As the total protein, total activiy and percentage yield decreases the specific activity and purification fold increases.

\section{Optimization of Environmental Factors Effecting the Partially Purifed} Enzyme

Environmental factors like the $\mathrm{pH}$ of the buffer used in the casein assay, $\mathrm{pH}$ stability of the enzyme, temperature used in the assay, thermal stability of the enzyme, and the incubation time used in the assay were optimized (Fig. 5, Fig. 6 , and Fig. 7). These factors were optimized together with the partially purified enzyme. High activity in the different environmental factors were applied and used as basis for further study.

The neutral and alkaline proteases were subjected to different temperatures during the assay. The optimum temperature for neutral protease was at $30^{\circ} \mathrm{C}$ and $40^{\circ} \mathrm{C}$ for alkaline protease. Both enzymes were subjected to different temperatures prior to use in the assay (Pagare et al(2009); El-Safey and AbdulRaouf (2004); Kumar et al(2002)). Both of the enzymes are stable in five different temperatures. Neutral protease showed the highest activity at 30 minutes and decreased its activity as the incubation time increased. While the alkaline protease had its highest activity at 90 minutes and decreased its activity as the incubation time increased. Both enzymes showed that the time of incubation had an effect on the proteolytic activity of the enzymes.
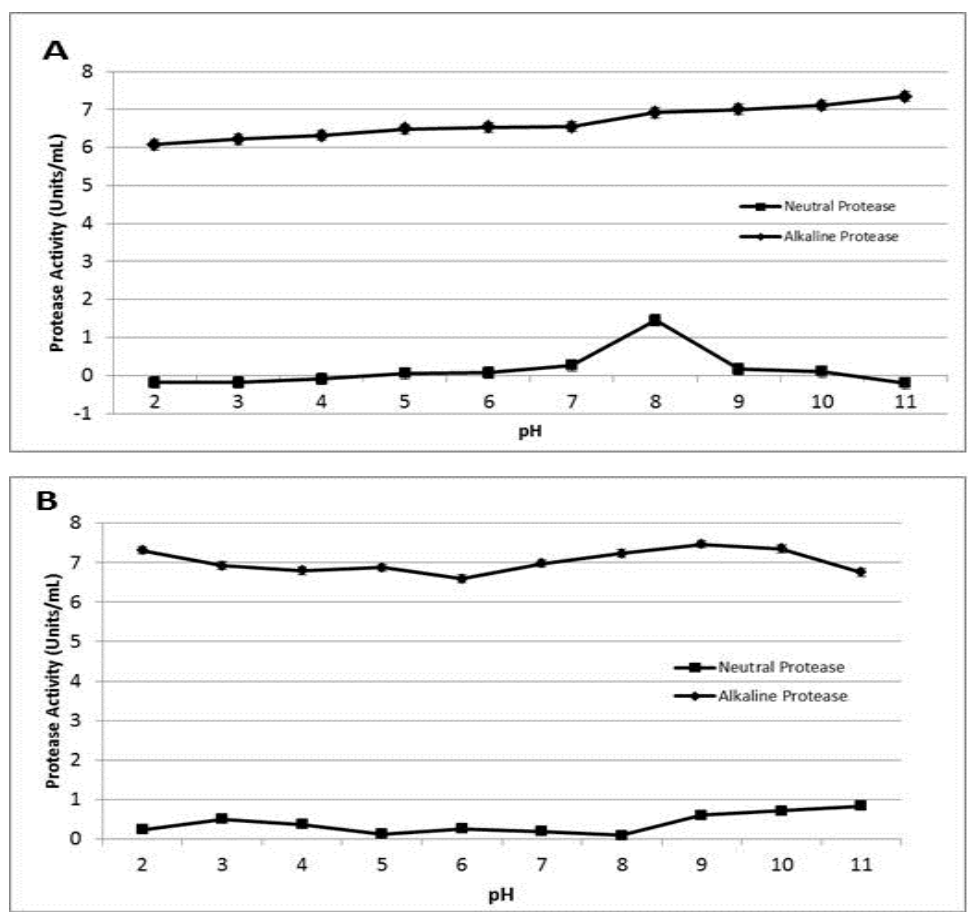

Figure 5 (A) Optimum $\mathrm{pH}$ environment for partially purified neutral and alkaline proteases reaction. (B) $\mathrm{pH}$ stability of partially purified neutral and alkaline proteases incubated for 48 hours.
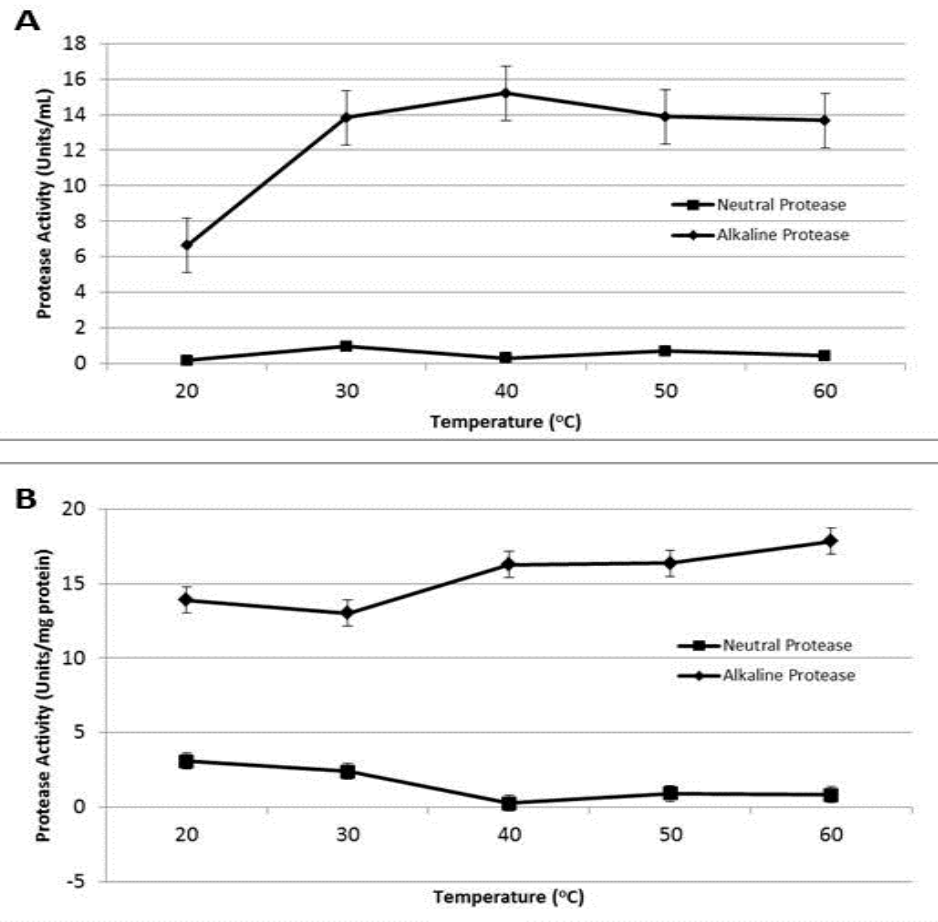

Figure 6 (A) Optimum thermal environment for partially purified neutral and alkaline proteases reaction. (B) Thermal stability of partially purified neutral and alkaline proteases incubated for 1 hour. 
Table 1 Neutral Protease Purification Table

\begin{tabular}{lccccc}
\hline Method & $\begin{array}{c}\text { Total Protein } \\
(\mathrm{mg} / \mathrm{mL})\end{array}$ & $\begin{array}{c}\text { Total Activity } \\
(\text { Units/mL) }\end{array}$ & $\begin{array}{c}\text { Specific Activity } \\
(\text { Units/mg protein })\end{array}$ & \% Yield & Purification fold \\
\hline Crue Enzyme & 17.84 & 2.40 & 0.13 & 100 & 1.00 \\
$\begin{array}{l}\text { Ammonium Sulfate } \\
\text { Precipitation }\end{array}$ & 2.28 & 2.23 & 0.98 & 93.28 & 7.32 \\
$\begin{array}{l}\text { Desalting by Dialysis } \\
\begin{array}{l}\text { Gel-Filtration Chromatography } \\
\text { Sephadex G-75 }\end{array}\end{array}$ & 1.12 & 1.56 & 1.39 & 64.95 & 10.37 \\
\hline
\end{tabular}

Table 2 Alkaline Protease Purification Table

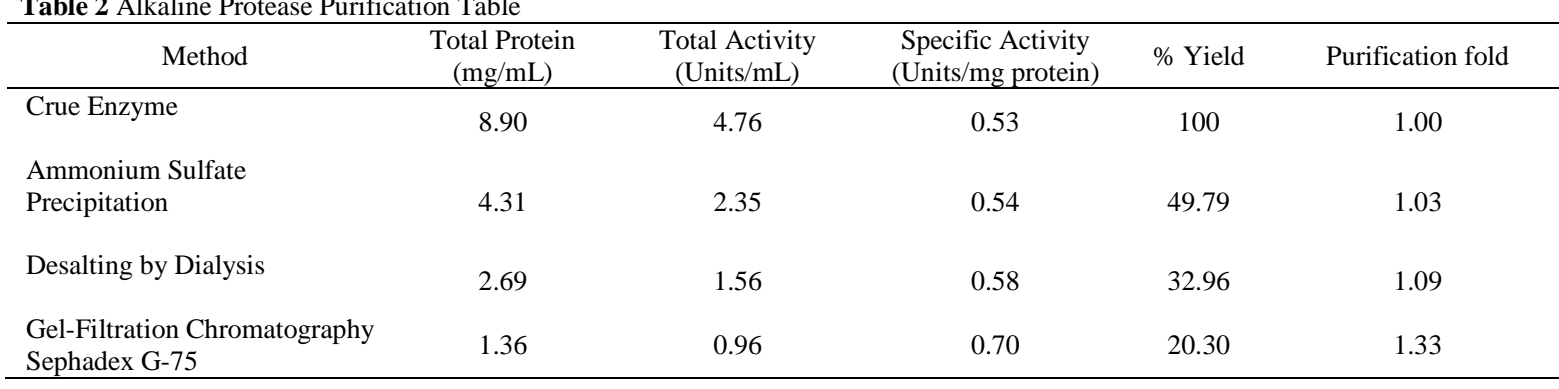

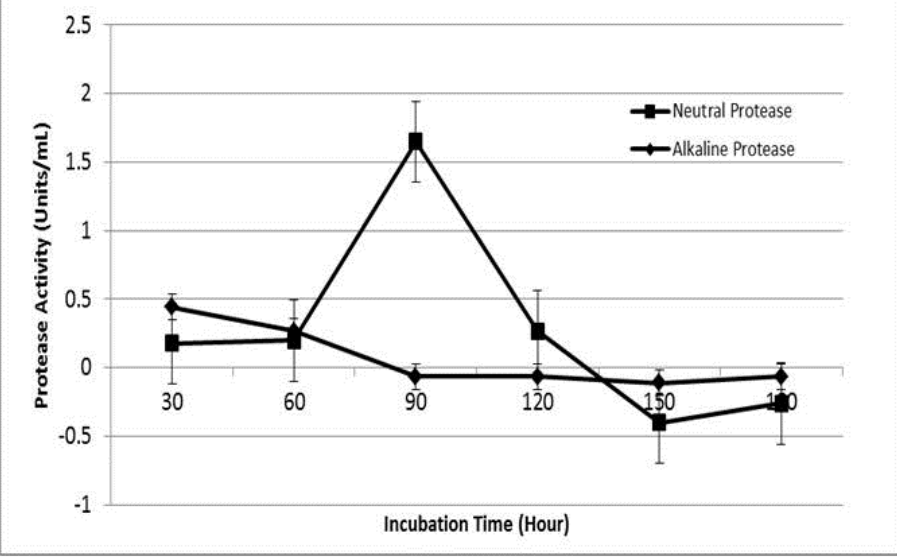

Figure 7 Optimum incubation time of reaction for both partially purified neutral protease and alkaline proteases.

\section{Homogeneity determination using SDS-PAGE}

Fractions collected from the gel chromatography with high proteolytic activity were analyzed by using SDS-PAGE to determine the presence of proteins and its molecular weight. Protein standard used in this analysis were Insulin B Chain (3kDa), Aprotinin (6kDa), Lysozyme (14kDa), Myoglobin Red (17kDa), Carbonic Anhydrase (28kDa), Alcohol Dehydrogenase (38kDa), Glutamic Dehydrogenase $(49 \mathrm{kDa})$, BSA $(62 \mathrm{kDa})$, Phosphorylase $(98 \mathrm{kDa})$, Myosin $(188 \mathrm{kDa})$. Molecular weight was determined by linear semilogarithmic plot of the molecualar weights of standard and its Rf values. Based on the Rf value of the of the purified neutral protease, the calculated molecular weight of the protein band was $65.4 \mathrm{kDa}$ which coincide in the band of BSA and Phosphorylase (Fig. $8 \mathrm{~A}$ ). While based on the $\mathrm{Rf}$ values of the purified alkaline protease, the calculated molecular weight of the band was $8 \mathrm{kDa}$.
$\mathbf{A}$

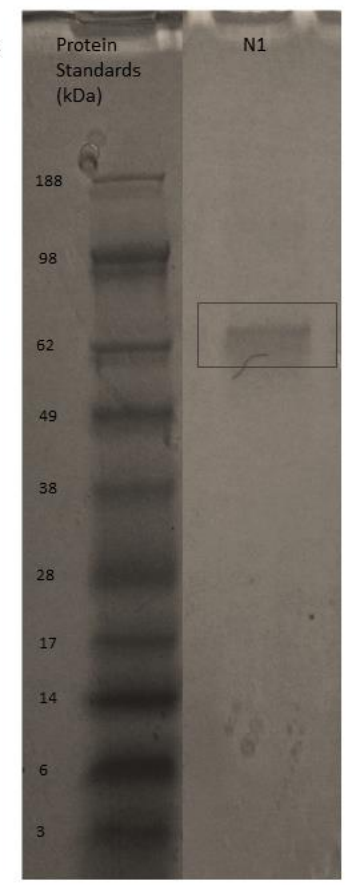

B

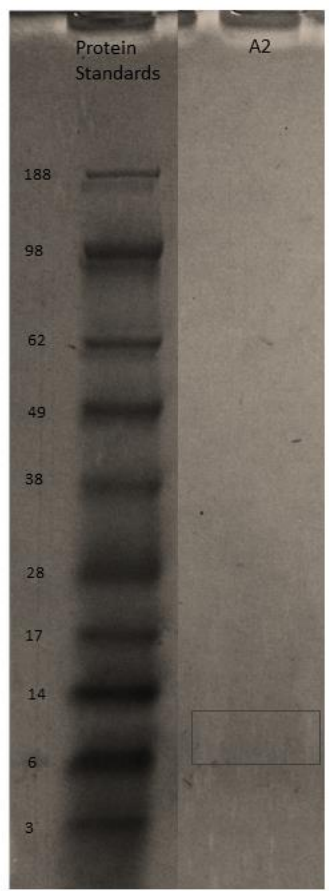

Figure 8 (A) SDS-PAGE molecular weight determination of partially purified neutral proteases. (B) SDS-PAGE molecular weight determination of partially purified alkaline proteases.

\section{DISCUSSIONS}

Bacillus subtilis is known to produce many kind of enzymes, namely, RNAse, alkaline phosphatase, levansucrase, amylase and several proteases (El-Safey and Abdul-Raouf, 2004). Neutral and alkaline proteases were the two enzymes from B. subtilis that were of interest in this study. Data presented from the optimization of fermentation medium up to the characterization of the enzyme itself showed that B.subtilis was producing extracellular proteases as part of its defense mechanism and as part of its metabolism. In this study, six strains of B.subtilis were screened for the production of proteases, optimized the fermentation medium for high production of proteases. Since USTCMS 1011 showed high proteolytic activity in the optimization of $\mathrm{pH}$ and temperature of the media of both neutral and alkaline protease (Figs1 and 2), it was used for further experiments and for the production of two proteases. El-Safey and Abdul-Raouf (2004), noted in their study that optimum protease production by B. subtilis may range from $30^{\circ} \mathrm{C}$ to $45^{\circ} \mathrm{C}$. The $\mathrm{pH}$ of media noted in the study of El-Safey and Abdul-Raouf (2004) with the optimum protease production was at $\mathrm{pH} 7$ and at the $\mathrm{pH}$ range of 6.0 to 8.0 and for alkaline stable protease at $\mathrm{pH} 11$. The results of 
this study conformed that optimum fermentation condition for protease production was at thermal range of $30^{\circ} \mathrm{C}$ to $45^{\circ} \mathrm{C}$ and has a buffer $\mathrm{pH}$ of 6.0 to 8.0 for neutral condition and 9.0 to 11.0 for alkaline condition.

Garbanzos with yeast extract significantly showed the highest proteolytic activity among the other protein source $(\mathrm{p}<0.05)$. Garbanzos is known to have a value of $8.86 \mathrm{~g}$ of protein per $100 \mathrm{~g}$, while mung bean and black bean have 7.02 and 1.08 g respectively and yeast extract added in the media is also an established protein source.

The abovementioned protein source were used because of its lower unit value and is more economical than using pure yeast extract as protein source. Result showed that garbanzos was a good substitute to soybean which was use in research of protease production of Espino et al. (1996).; soy bean has been considered to have high protein content than other legumes and other anima products and contains all essential amino acids and all essential fats while garbanzos also contain high protein, essential fats, and nutrients; and since garbanzos has a lower economic value than soy bean, it was used in protease production experiment as a substitute to soybean with a little amount of yeast extract for additional protein source in the media rather than using pure yeast extract. Ammonium sulfate was also noted to be good source of nitrogen for B. subtilis as per El-Safey and Abdul-Raouf (2004).

The different sources of carbohydrate used were dextrin, honey, banana and mango peelings. Statistical analysis showed significant differences among different carbohydrate sources. Optimum proteolytic activity was found when dextrin was used $(\mathrm{p}<0.05)$ as carbohydrate source in both alkaline and neutra proteases activity of $0.4954 \pm 0.032$ and $0.6466 \pm 0.05 \mathrm{U} / \mathrm{mg}$ protein, respectively. Results are shown in Fig. 3B. Based on the studies conducted, dextrin served as the most prominent carbohydrate source because of its structure which consists of branching unit of glucose and easily for the bacteria to degrade and turn it into glucose subunits, which is the primary source of carbon for bacteria (Espino $\boldsymbol{e}$ $\boldsymbol{a l}$, 1996). In addition, honey, banana and mango peelings were found to have anti-bacterial properties thereby attaining lower proteolytic activities. El-Safey and Abdul-Raouf (2004) also noted in his study that lactose and sucrose were also very good sources of carbon for the bacteria while glucose supressed protease production

Incubation time of 72 hours was used for the production of protease in both alkaline and neutral protease together with other fermentation parameters because the results showed high production of protease in those conditions and that incubation time was also the optimum incubation time for protease production as performed by Espino et al (1996), Das and Prasad (2010) and Kumar et at (2002).

The $\mathrm{pH}$ of the culture strongly affects many enzymatic processes and transport of compounds across the cell membrane Das and Prasad (2010). The optimum pH for partially purified neutral proteases were obtained as $\mathrm{pH} 8$ and at $\mathrm{pH} 11$ for alkalaine proteases. Neutral protease had no activity on acidic and basic $\mathrm{pH}$ while the alkaline protease showed an increase in the activity as the $\mathrm{pH}$ used in the assay increases. Both proteases were observed to be stable at pH 2-11. El-Safey and Abdul-Raouf (2004), Adinarayana et al (2003) and Ahmed et al (2011) noted in their research that neutral protease has an optimal activity at $\mathrm{pH} 7.0$ and was stable at $\mathrm{pH}$ ranging from 2.0 to 9.0 while the alkaline protease has an optimum activity at $\mathrm{pH} 11$ and was stable at $\mathrm{pH}$ ranging from 5.0 to 12.0 . Optimum temperature for partially purified protease for it to be fully active was observed in this study at $30^{\circ} \mathrm{C}$ and $40^{\circ} \mathrm{C}$; but according to El-Safey and AbdulRaouf (2004), Ahmed (2011) their purified protease were active at $35^{\circ} \mathrm{C}$ to $37^{\circ} \mathrm{C}$ $40^{\circ} \mathrm{C}$ and was stable at $25^{\circ} \mathrm{C}$ to $42^{\circ} \mathrm{C}$. In that note, results obtained in this study conform that purified proteases are active at buffer $\mathrm{pH}$ of 7.0 to 8.0 for neutra proteases and $\mathrm{pH} 9.0$ to 11.0 for alkaline proteases and that they are stable at $\mathrm{pH}$ 2.0 to 12.0 . Also, purified proteases are active at thermal incubation of $30^{\circ} \mathrm{C}$ to $40^{\circ} \mathrm{C}$ and are active at $25^{\circ} \mathrm{C}$ to $42^{\circ} \mathrm{C}$

Based on literatures, alkaline serine protease has a lower molecular weight than neutral protease. Adinaraya et al. (2003), characterized their isolated alkaline protease with a molecular weight of $15 \mathrm{kDa}$ to $19 \mathrm{kDa}$. Neutral protease in the other hand has a molecular weight of 44kDa and 50kDa (Younis et al, 2009).

\section{CONCLUSION}

Among the six tested B. subtilis, strain USTCMS 1011 had the highest proteolytic activity for neutral and alkaline protease. The optimum conditions for neutral protease were $\mathrm{pH} 7$ and $37^{\circ} \mathrm{C}$ while for alkaline protease, $\mathrm{pH} 9$ and $30^{\circ} \mathrm{C}$ High proteolytic activity was observed both in neutral and alkaline proteases using garbanzos with yeast extract as the protein source and dextrin as the carbohydrate source. Furthermore, partially purified proteases have an optimum $\mathrm{pH}$ of 8 at $30^{\circ} \mathrm{C}$ for 90 min that is also stable at $\mathrm{pH} 2-11$ and at $30-40^{\circ} \mathrm{C}$ for neutral proteases. On the oher hand, alkaline protease had an optimum $\mathrm{pH}$ of 11 at $40^{\circ} \mathrm{C}$ for an incubation period of 30 minutes and was also stable at $\mathrm{pH} 2-11$ and at $30-40^{\circ} \mathrm{C}$. Molecular weight of enzyme produced was noted to be at $64.5 \mathrm{kDa}$ for neutral proteases and $8 \mathrm{kDa}$ for alkaline proteases.

Acknowledgement: The authors gratefully acknowledge the Department of Biochemistry, Faculty of Pharmacy and the Molecular Biology Laboratory, Research Center for Natural and Applied Sciences in the University of Santo
Tomas and also the National Institute of Molecular Biology and Biotechnology $(\mathrm{BIOTECH})$ in UPLB for providing the facility to carry out this research succesfully. The authors also acknowledge Ms. Anna BeatrizR. Mayor for editing and for her support in this research.

\section{REFERENCES}

ADINARAYANA, K., ELLAIAH, P., PRASAD, D.S. 2003. Purification and partial characterization of thermostable serine alkaline protease from a newly isolated Bacillus subtilis PE-11, AAPS PharmSciTech.4(4), 440-448 (http://dx.doi.org/10.1208/pt040456)

AHMED, I., ZIA, M.M., IQBAL, H.M.N. 2011. Purification and Kinetic Parameters Characterization of an Alkaline Protease Produced from Bacillus subtilis through Submerged Fermentation Technique, World Applied Sci J, 12(6), 751-757.

AKCAN, N., UYAR, F. 2011. Production of extracellular alkaline protease from Bacillus subtilis RSKK96 with solid state fermentation. Eurasia J Biosci, 5:6472. (http://dx.doi.org/10.5053/ejobios.2011.5.0.8)

AGARWAL, D., PATIDAR, P., BANERJEE, T., PATIL, S. 2004. Production of alkaline protease by Penicillium sp. Under SSF conditions and its application to soy protein hydrolysis, Process Biochem, 39(8), 977-981 (http://dx.doi.org/10.1016/S0032-9592(03)00212-7)

DAS, G., PRASAD, M.P. 2010. Isolation, Purification, and Mass Production of Protease Enzyme from Bacillus subtilis, Int. Res. J. of Microbiol, 1(2), 26-31 EL-SAFEY E.M., ABDUL-RAOUF, U.M. 2004. Production, purification and characterization of protease enzyme from Bacillus subtilis, International Conferences for Development and the Environment in the Arab World, Assiut University, Egypt. 14-44.

ESPINO, T.M., CENTENO, S.M., MERCADO, M.A., MINAMURA, N. 1996 Purification and Partial Characterization of Alkaline Protease from Bacillus subtilis NRRL B-3749 (BIOTECH 1679), Phil. J. of Biotechnol, 7(1), 25-34

JISHA, V.N., SMITHA, R.B., PRADEEP,S., SREEDEVI, S., UNNI, K.N., SAJITH, S., PRIJI, ., JOSH, M.S., BENJAMIN, S. 2013. Versatility of Microbial Proteases. Adv Enzyme Res, 1(3): (http://dx.doi.org/10.4236/aer.2013.13005)

KUMAR, A. SACHDEV, A., BALASUBRAMANYAM, S.D., SAXENA, A.K 2002. Optimization of Conditions for Production of Neutral and Alkaline Protease from species of Bacillus and Pseudomonas, Indian J. of Microbiol, 42:233-236

LAZIM, H., MANKAI, H., SLAMA, N., BARKALLAH, I., LIMAM, F. 2009. Production and otimization of thermophillic alkaline protease in solid-state fermentation by Streptomyces sp. CN902. J Ind Microbiol Biotechnol, 36: 531537. (http://dx.doi.org/10.1007/s10295-008-0523-6)

LI, J., YANG, Q., ZAO, L-H. 2009. Purification and Characterization of a Nove Antifungal Protein from Bacillus subtilis strain B27, J. of Zhejiang Univ. Sci. B, 10(4), 264-272. (http://dx.doi.org/10.1631/jzus.B0820341)

PADMAPRIYA, M., CHRISTUDHAS WILLIAMS, B. 2012. Purification and characterization of neutral protease enzyme from Bacillus subtilis, J. Microbiol. Biotech. Res., 2(4), 612-618.

PAGARE, R.S., RAMDASI, A.M., KHANDELWAL, S.R., LOLHANDE, M.D., AGLAVE, B.A. 2009. Production and Enzyme Activity of an Extracellular Protease from Aspergillus niger and Bacillus subtilis, Int. J. of Biotechnol and Biochem, 5(3), 335-342.

SEPAHY, A.A., JABALAMELI, L. 2011. Effect of Culture Conditions on the Production of an Extracellular Protease by Bacillus sp. Isolated from Soil Sample of Lavizan Jungle Park. Enzyme Res, 1-7. (http://dx.doi.org/10.4061/2011/219628)

SHAEEN, M., SHAH, A.A., HAMEED, A., HASAN, F. 2008. Influence of Culture Conditions on Production and Activity of Protease from Bacillus subtilis BS1, Pak. J. Bot., 40(5), 2161-2169

YOUNIS, M.A.M., HEZAYEN, F.F., NOUR-ELDEIN, M.A., SHABEB, M.S.A 2009. Production of Protease in Low-Cost Medium by Bacillus subtilis KO strain, Global J. of Biotechnol and Biochem, 4(2), 132-13

ZHENG, G., SLAVIK, M.F. 1999. Isolation, Partial Purification and Characterization of Bacteriocin Produced by a newly Isolated Bacillus subtilis, Lett. Appl. Microbiol, 28(5), 363-367. (http://dx.doi.org/10.1046/j.13652672.1999.00545 